\title{
Tourism in Continental Ecuador and the Galapagos Islands: An Integrated Coastal Zone Management (ICZM) Perspective
}

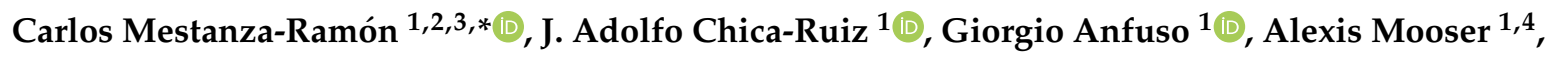 \\ Camilo M. Botero ${ }^{5,6}$ and Enzo Pranzini ${ }^{7}$ \\ 1 Facultad de Ciencias del Mar y Ambientales, Universidad de Cádiz, Polígono Río San Pedro s/n, \\ 11510 Puerto Real, Cádiz, Spain; adolfo.chica@uca.es (J.A.C.-R.); giorgio.anfuso@uca.es (G.A.); \\ alexis.mooser@alum.uca.es (A.M.) \\ 2 Escuela Superior Politécnica de Chimborazo, Sede Orellana, YASUNI-SDC Research Group, \\ El Coca EC220001, Ecuador \\ 3 Instituto Tecnologico Supeior Oriente, La Joya de los Sachas 220101, Orellana, Ecuador \\ 4 Dipartimento di Scienze e Tecnologie, Università di Napoli Parthenope, 80143 Naples, Italy \\ 5 Grupo Joaquín Aarón Manjarrés, Escuela de Derecho, Universidad Sergio Arboleda, Santa Marta 470001, \\ Colombia; camilo.botero@usa.edu.co \\ 6 Grupo de Investigación en Sistemas Costeros, PlayasCorp, Santa Marta 470001, Colombia \\ 7 Dipartimento di Scienze della Terra, Università di Firenze, 50121 Firenze, Italy; enzo.pranzini@unifi.it \\ * Correspondence: cmestanza@ug.uchile.cl or carlos.mestanza@espoch.edu.ec; Tel.: +593-9-9883-0801
}

Received: 28 April 2020; Accepted: 6 June 2020; Published: 9 June 2020

\begin{abstract}
Tourism in coastal areas is becoming increasingly important in Integrated Coastal Zone Management (ICZM) as an integrated approach that balances the requirements of different tourist sectors. This paper analyzes ICZM in continental Ecuador and the Galapagos Islands from the perspective of the $3 \mathrm{~S}$ tourism, and presents its strengths, weaknesses, opportunities and threats (SWOT). The methodology used was based on a literature review of ten aspects of the highest relevance to ICZM, i.e., Policies, Regulations, Responsibilities, Institutions, Strategies and Instruments, Training, Economic Resources, Information, Education for Sustainability, and Citizen Participation. The results highlight four aspects as strengths (Policies, Responsibilities, Institutions and Citizen Participation), while the most notable weaknesses were Regulations and Education for sustainability. Strategies and Instruments, as well as Information, were identified as opportunities to stand out. The main threats were Economic Resources and Training. Ecuador does not have clearly established public policies that would allow for the integrated management of $3 \mathrm{~S}$ tourism and be considered as productive, valuable alternatives. It is necessary to consolidate and promote $3 \mathrm{~S}$ tourism as a State policy and as a means to improve the economies in coastal areas. Finally, Ecuador needs to overcome negative changes in the macroeconomic environment and reverse its current deteriorated image.
\end{abstract}

Keywords: SWOT analysis; coastal; 3 S tourism; planning; beach

\section{Introduction}

Issues related to the environment, tourism and its management in coastal areas are becoming increasingly important after the rapid growth of mass tourism in recent decades [1,2]. Despite the existence of policies, laws and regulations, most coastal areas are affected by environmental degradation and face a decline in environmental quality caused by the impacts of tourism [3,4].

Coastal areas have great natural and scenic value and represent a special environment that constitutes a transition between the terrestrial and marine ecosystems [5,6]. They show great diversity 
and represent an indispensable element for human subsistence [7,8]. Ecosystems are fragile and limited, and therefore require adequate management due to the existence of diverse problems in different sectors and at different levels. For instance, there are environmental, political and socioeconomic problems that are mainly caused by a lack of planning and coordination [9]. Therefore, the information that can be obtained from the analysis of the coastal environment and its changes due to erosive processes, as well as biological and anthropogenic activities, allows researchers to identify how coastal systems are changing, and what are the main causes of such alterations [5].

Integrated Coastal Zone Management (ICZM) in Latin American countries such as Cuba [10], Mexico [11], Peru [12], Uruguay [13], Argentina [14], Brazil [15], Chile [16], Ecuador [17] and Colombia [18] has shown progress in recent decades [19]. Successful examples of integrated management, which have contributed to the development of coastal zones, have been demonstrated at a global level [20-22]. ICZM seeks sustainability by enhancing meaningful citizen participation and integrating different activities in a rational and coordinated approach $[23,24]$. This is achieved by developing social and professional capacities through governmental and nongovernmental organizations. Solid scientific bases must be defined and articulated, and access to information with a transparent accountability system has to be guaranteed [25].

Coastal tourism management can be defined as a set of actions that leads to the achievement of certain tourist objectives (e.g., increasing the supply of services and destinations, participation of tourism in sustainability, institutional efficiency, development of talent) in coastal environments through the combination [26], distribution and disposition of material and human resources, the coordination, guidance and motivation of the different agents involved, and the evaluation of the effects according to the set objectives [27]. Tourism, as a collective social practice that generates economic activity, is essentially required to properly create and manage employment and public wealth by making efficient and sustainable use of available, scarce and often irreproducible resources [28,29].

In recent decades, tourism focused on the enjoyment of "Sun, Sand and Sea" (3S) has shown a significant increase [30]. Despite coastal areas accounting for only $4 \%$ of the total land surface, they host a third of the Earth's population [31]. The increase in tourism activities in coastal areas contributes to the degradation of ecosystems. Worldwide, in most countries, coastal regulations are often ineffective and lack adequate ICZM regulations. Beaches have considerable value to the tourism industry, and this makes their protection essential to the economy $[17,32,33]$.

ICZM is a dynamic process in which a coordinated strategy for the distribution of environmental, socio-cultural and institutional resources is developed and implemented in order to achieve the conservation and sustainable use of coastal zones. Successful $3 S$ tourism development is based on hierarchical management (Figure 1), including beach tourism, coastal tourism and the integrated management of the coastline $[17,34]$.

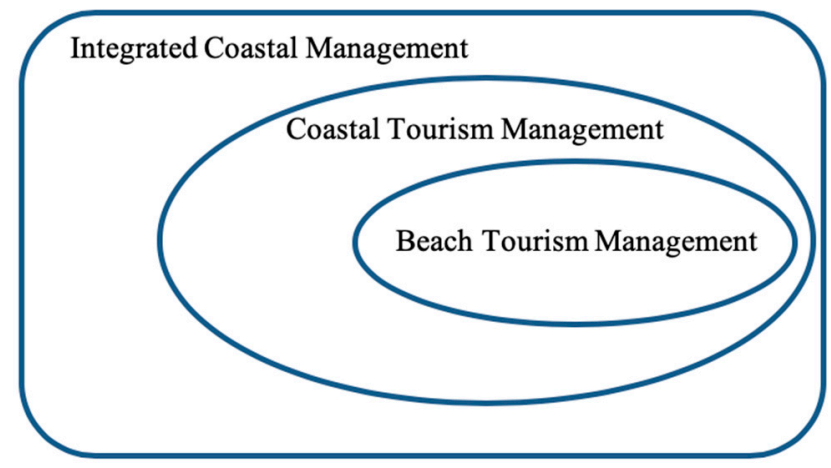

Figure 1. Example of the hierarchy required in the management of the coastline for tourism purposes [34].

ICZM must consider that the diverse ecosystems are interconnected from the highest elevation to the continental plateau, and through the diversity of their elements. A suitable instrument to articulate a model of balanced tourist development in the coastal zone is a Master Plan for Tourist Spaces based 
on the rational management of resources $[35,36]$. This approach tries to establish two fundamental principles for the future of tourism: (i) the need to overcome the model of continuous growth, and (ii) the mechanisms of cooperation between agents and institutions to properly understand the impacts of interventions in the territory $[37,38]$. The environmental impacts of erosion processes have been extensively investigated, but it is important to highlight the threat that erosion represents for the economic growth of the tourism sector [33].

The Ecuadorian coastal population in the period from 1950 to 2010 showed a significant increase. According to the latest official figures from 2015, the coastal population increased from 33\% (902,173) of the total population in 1950 to $50 \%(7,219,249)$ in $2010[39,40]$. This growth has caused an increase in the impact on coastal ecosystems, evidencing a decline in the provision and functionality of services based upon natural systems [39,41]. According to Ecuador's Ministry of Tourism, 57\% of international visitors that enter Ecuador are essentially interested in tourist activities such as cultural tourism (44\%), ecotourism (30\%), 3S tourism (21\%), adventure tourism (4\%) and other types of tourism (1\%) [42].

Many studies have proposed tools to support and improve decision making on tourist beaches, from very simple characterizations to highly complex standards (e.g., classifications based on their geomorphology) [43-45]. Within those beach management tools, the certification schemes are the most holistic, although this depends on their specific requirements [46]. In sum, despite the fact that many coastal destinations do not apply management policies, they are not novel issues for beach tourism.

The main objective of this study is to analyze ICZM in mainland Ecuador and the Galapagos Islands from the perspective of 3S tourism, and to discuss the strengths, weaknesses, opportunities, and threats (SWOT) involved in this process in the face of constant change, in order to finally establish clear and precise recommendations for the improvement of suitable management actions and policies.

\section{Materials and Methods}

\subsection{The Study Area}

Concerning biodiversity, Ecuador occupies the 17th place in the world. In recent years, Ecuador has maintained an increase in tourist arrivals due to its natural beauty. Its territory covers an area of $256,370 \mathrm{~km}^{2}$, including mainland Ecuador and the Galapagos Islands (Figure 2) [47]. It is located in the north-west of South America, bordering Colombia to the north, Peru to the south and east and the Pacific Ocean to the west [48]. The country is divided into four regions: Galapagos, Coast, Andes and Amazon [49].

Ecuador has a population of 17.5 million inhabitants, of which 8.6 million $(49.3 \%)$ live in coastal provinces [50]. Its Pacific coastal area includes the provinces of Esmeraldas, Manabí, Santa Elena, Guayas and El Oro. The Galapagos Archipelago consists of 13 main islands, 17 islets and a variety of ancient rocks $[47,49]$. This paper focuses specifically on three coastal provinces and one island province. The area encompasses a total of 22 cantons (Table 1) [47].

Table 1. Investigated cantons in the continental Ecuador and Galapagos Islands. The names of the provinces are in bold.

\begin{tabular}{llll}
\hline \multicolumn{1}{c}{ Esmeraldas } & \multicolumn{1}{c}{ Manabí } & Santa Elena & Galápagos \\
\hline & Pedernales & & \\
Jama & & \\
San Lorenzo & San Vicente & & \\
Rloy Alfaro Verde & Sucre & Salinas & Santa Cruz \\
Esmeraldas & Portoviejo & Santa Elena & San Cristóbal \\
Atacames & Jaramijó & La Libertad & Isabela \\
Muisne & Manta & & \\
& Montecristi & & \\
& Jipijapa & & \\
\hline
\end{tabular}




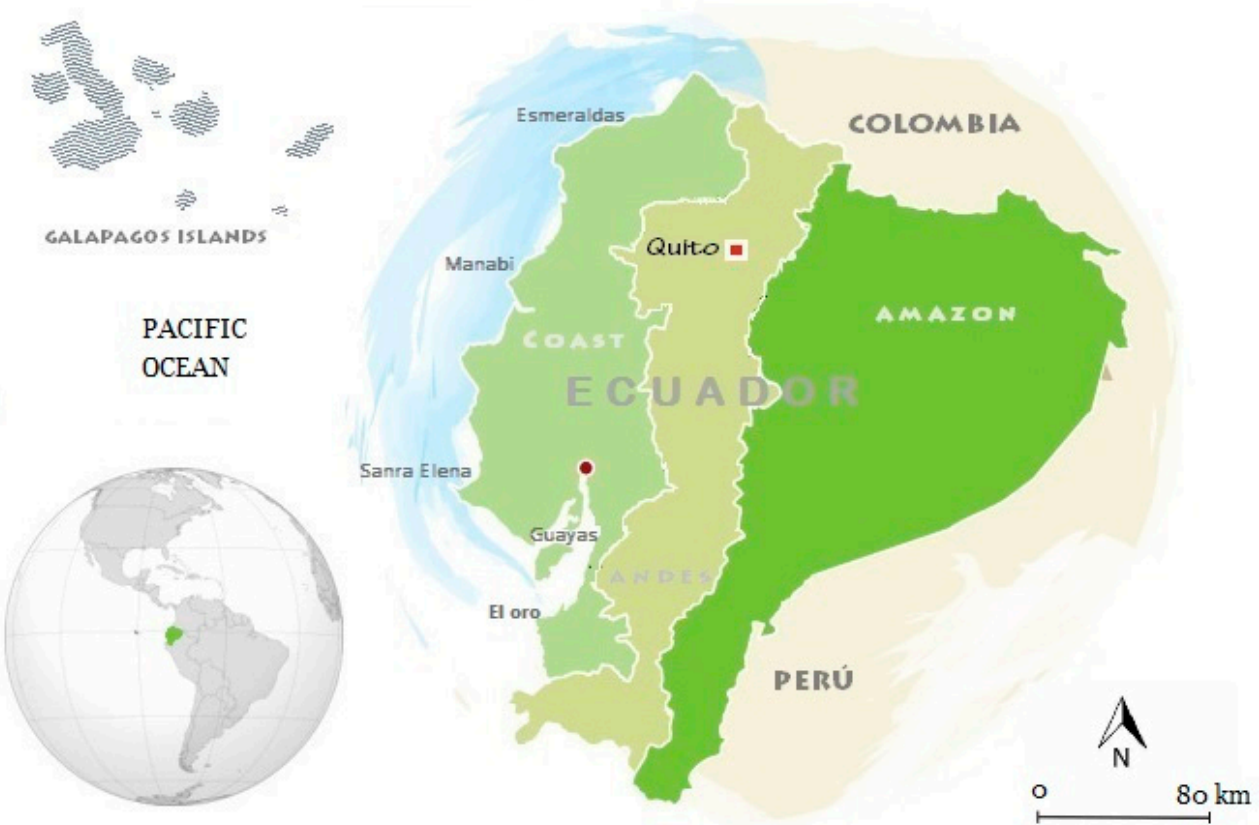

Figure 2. Map of Ecuador, study area.

\subsection{Methods and Sources}

The methodology was divided into two sections. The first analyses ICZM in mainland Ecuador and the Galapagos Islands from the perspective of $3 S$ tourism, using ten aspects known as the Decalogue [41,51]: Policies, Regulations, Management Strategies, Institutions, Instruments, Training, Economic Resources, Literacy and Information, Education for Sustainability and Citizen Participation. The second section is focused on discussing the strengths, weaknesses, opportunities and threats (SWOT) found in the area, in order to finally establish clear and precise recommendations for the improvement of ICZM.

\subsubsection{Sea, Sun and Sand (3S) Tourism}

The methodology of the Decalogue for Integrated Coastal Zone Management [41] consists of ten strategic indicators for coastal management in terms of sustainability and governance, which are used as basic aspects in public policies for proper coastal management. This methodology has been tested in several Latin American countries, such as Peru, Cuba, Mexico, Uruguay, Argentina, Brazil, Chile, Colombia and Ecuador [10-17]. In the present study, the Decalogue (Table 2) is used to analyze the current state of ICZM in mainland Ecuador and the Galapagos Islands from the perspective of $3 S$ tourism.

Table 2. Decalogue for the analysis of the current state of ICZM in mainland Ecuador and the Galapagos Islands from the perspective of the $3 S$ tourism.

\begin{tabular}{lll}
\hline \multicolumn{1}{c}{ Aspect } & \multicolumn{1}{c}{ 3S Tourism Objective } \\
\hline 1. Policies & To determine whether there is an ICZM policy for 3S tourism. \\
2. Regulations & To analyze the base norms that regulate the 3S tourism. \\
3. Responsibilities & To determine the scheme of the distribution of responsibilities. \\
4. Institutions & To specify the institutions that are the most involved in tourism activities. \\
5. Strategies and Instruments & To identify strategic and operational instruments of interest. \\
6. Training & To analyze the training plans for administrators and managers. \\
7. Economic resources & To understand the budget for its sustenance and operation. \\
8. Information & To determine the level of knowledge about the management model. \\
9. Education for sustainability & To identify the main educational initiatives for citizens and general users. \\
10. Citizen participation & To document decision-making methods and citizen participation. \\
\hline
\end{tabular}


The study is based on a bibliographical analysis of works published between 2007 and 2019 on the ten aspects described in the Decalogue, and focuses solely on the $3 \mathrm{~S}$ tourism. The analyzed documents were mainly policies, development plans, regulations (laws, ministerial agreements, ordinances, among others) and policy proposals. This significant information contributed to understanding the current situation and improvements in Ecuador's $3 S$ tourism.

To complement the bibliographic review, in the first months of 2018, 65 beaches were visited and classified according to their type and tourist use in four categories (i.e., urban, rural, village and remote) (Table 3). Another important grouping was made considering human occupation and use, and they were classified as remote, rural, village and urban [43].

Table 3. Location and main characteristics of investigated sites: name, province, type and protection feature.

\begin{tabular}{|c|c|c|c|c|c|c|c|}
\hline Prov. & $\mathbf{N}$ & Beach & Type & Prov. & $\mathbf{N}$ & Beach & Type \\
\hline \multirow{19}{*}{$\underset{\substack{\infty \\
\infty}}{\stackrel{\infty}{\mathbb{1}}}$} & 1 & Escondida * (1) & Remote & \multirow{13}{*}{ 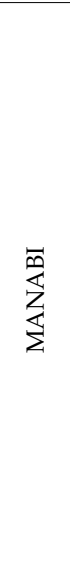 } & 35 & Punta (del Fraile) & Village \\
\hline & 2 & Isla Portete & Rural & & 36 & Puerto Cayo & Village \\
\hline & 3 & Punta Galera * (1) & Rural & & 37 & Puerto Lopez & Urban \\
\hline & 4 & Africa & Remote & & 38 & Pedernales & Urban \\
\hline & 5 & Paufi & Rural & & 39 & Canoa & Village \\
\hline & 6 & Estero Platano * (1) & Village & & 40 & San Mateo & Village \\
\hline & 7 & (Rocafuerte) & Rural & & 41 & Crucita & Urban \\
\hline & 8 & Same 2 & Remote & & 42 & Santa Marianita & Village \\
\hline & 9 & Las Palmas & Urban & & 43 & Machalilla & Village \\
\hline & 10 & Sua & Urban & & 44 & San Vicente & Urban \\
\hline & 11 & San Francisco * (1) & Village & & 45 & Murciélago & Urban \\
\hline & 12 & Río Verde & Village & & 46 & Tarqui & Urban \\
\hline & 13 & Same 1 & Village & & 47 & Bahía de Caráquez & Urban \\
\hline & 14 & Bocana del Lagarto & Village & \multirow{8}{*}{ 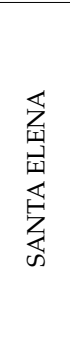 } & 48 & Rosada * (5) & Rural \\
\hline & 15 & Mompiche & Village & & 49 & Olon & Village \\
\hline & 16 & Las Peñas & Village & & 50 & Punta Carnero & Urban \\
\hline & 17 & Tonsupa & Urbana & & 51 & Puntilla de Santa Elena * (6) & Rural \\
\hline & 18 & Atacames & Urban & & 52 & Ayangue * (5) & Village \\
\hline & 19 & Las Palmas & Urban & & 53 & Montañita & Urban \\
\hline \multirow{15}{*}{ 龸 } & 20 & Los Frailes * (3) & Remote & & 54 & Salinas Chipipe & Urban \\
\hline & 21 & San José $2 *(4)$ & Remote & & 55 & Salinas San Lorenzo & Urban \\
\hline & 22 & Cabuyal & Remote & \multirow{13}{*}{ 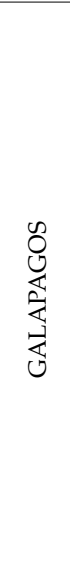 } & 56 & El Garrapatero * (2) & Remote \\
\hline & 23 & Punta Prieta & Remote & & 57 & Puerto Chino * (2) & Remote \\
\hline & 24 & Salango $2 *(3)$ & Remote & & 58 & Tortuga Bay * (2) & Remote \\
\hline & 25 & Tasaste & Rural & & 59 & Mansa * (2) & Remote \\
\hline & 26 & Ayampe & Village & & 60 & Lobería * (2) & Remote \\
\hline & 27 & San José * (4) & Rural & & 61 & Punta Carola * (2) & Remote \\
\hline & 28 & San Lorenzo * (4) & Village & & 62 & Tijereta * (2) & Remote \\
\hline & 29 & La Tiñosa & Rural & & 63 & Ratonera * (2) & Village \\
\hline & 30 & Don Juan & Rural & & 64 & Estación * (2) & Village \\
\hline & 31 & Salango & Village & & 65 & Mann * (2) & Village \\
\hline & 32 & San Clemente & Rural & & 66 & Los Alemanes * (2) & Village \\
\hline & 33 & Sol & Rural & & 67 & Fl Carranator * (2) & UThan \\
\hline & 34 & Las Tunas & Rural & & 67 & EI Garrapatero (2) & Urban \\
\hline
\end{tabular}

* Protected Natural Area, (1) Galera San Francisco Marine Reserve, (2) Galapagos National Park, (3) Machalilla National Park, (4) Pacoche Coastal Marine Wildlife Reserve, (5) The Pelado Marine Reserve, (6) Puntilla de Santa Elena Coastal Marine Fauna Production Reserve. Type of beach: Urban = Beaches that have commerce and are freely accessible to the general public. Village $=$ Beaches outside the urban environment, with a small population with organized community services on a small scale. Rural = Beach located outside the urban environment and difficult to access by public transport and generally without public service facilities. Remote $=$ Beaches characterized by difficult access, i.e., no public transport [43]. 


\subsubsection{Sea, Sun and Sand (3S) Tourism SWOT}

After analyzing the Decalogue on $3 S$ tourism in continental Ecuador and the Galapagos Islands from an Integrated Coastal Zone Management (ICZM) perspective, a SWOT analysis was carried out to make recommendations for improvements. The researchers set up questions that identified strengths, weaknesses, opportunities and threats (Table 4).

Table 4. SWOT matrix and questions put to coastal managers.

\begin{tabular}{llll}
\hline \multicolumn{1}{c}{ Strengths } & \multicolumn{1}{c}{ Weaknesses } & \multicolumn{1}{c}{ Opportunities } & \multicolumn{1}{c}{ Threats } \\
\hline & What could be done & $\begin{array}{l}\text { Which trends are } \\
\text { affecting tourism and }\end{array}$ & $\begin{array}{l}\text { What things other } \\
\text { countries do better? }\end{array}$ \\
$\begin{array}{l}\text { What are the advantages? } \\
\text { better? }\end{array}$ & $\begin{array}{l}\text { What is done poorly? } \\
\text { What done well? }\end{array}$ & $\begin{array}{l}\text { Which opportunities can } \\
\text { arise from these trends? }\end{array}$ & $\begin{array}{l}\text { What obstacles does } \\
\text { tourism face? }\end{array}$ \\
\hline
\end{tabular}

Social and economic actors (e.g., Government managers, academics, private entrepreneurs and representatives of society) answered the questions. The interviews were conducted in February 2018. The expert judgment of researchers was used to analyze the data obtained from step two. Finally, similar arguments were then used to make recommendations for improvements.

\section{Results}

\subsection{Decalogue Analysis}

A description is presented of aspects of the Decalogue which were analyzed through a bibliographic review: Policies, Regulations, Management Strategies, Institutions, Instruments, Education and Training, Economic Resources, Literacy and Information, Education for Sustainability, and Citizen Participation.

\subsubsection{Policies}

The Interinstitutional Committee on the Sea and the Secretariat of the Sea were founded from the need to address and provide interdisciplinary institutional procedures. Until 2012, Ecuador was characterized by a lack of clear ocean and coastal policies. In 2012, prior to an analysis by the National Plan for Good Living 2009-2013, as articulated in the Intersectorial Agenda for the Sea with the Plan for Good Living 2013-2017, national ocean and coastal policies (Table 5) were established [52].

At present, Ecuador is in a process of transition in terms of its tourism policy. The Strategic Plan for the Development of Sustainable Tourism (SPDST) 2020 policy is currently about to expire. A new plan will come into effect, i.e., the National Tourism Plan 2030, that is a tool that will provide general guidelines for tourism management at the national level, and will guide the actions that must be taken to achieve sustainable, inclusive and accessible tourism development for the next decade. Based on the analysis and evaluation of the achievements of the SPSTD, and on the collection of information from primary sources-i.e., internal meetings, workshops developed by the Ministry of Tourism and interviews directed to key actors in the tourism industry-the elaboration of the current public policy began with the updating of the diagnosis of the country's tourism sector [48,49].

The Government of Ecuador is aligned with the policies of the United Nations and the World Tourism Organization on promoting inclusive tourism. In 2017, the Ministry of Tourism proposed the "Tourism Policy of Ecuador" document. It aimed to turn the country into a tourism reference in the region, making tourism a key element for sustainable social and economic development. The fundamental aspects that stand out are the identification of key aspects, the establishment of policies and the analysis of the expected impact in their application by the year 2030. 
Table 5. Ecuador's ocean and coastal policies.

\begin{tabular}{|c|c|}
\hline Axis & Policies \\
\hline Heritage & $\begin{array}{l}\text { Objective } 1 \text {. Conserve the natural and cultural heritage, ecosystems and } \\
\text { biological diversity inherent to the marine and coastal zone, respecting } \\
\text { the rights of nature in continental Ecuador, the Galapagos archipelago, } \\
\text { the territorial sea, the contiguous zone, the exclusive economic zone and } \\
\text { Antarctica. } \\
\text { Objective } 2 \text {. Prevent, control and mitigate pollution of national marine } \\
\text { spaces and coastal areas. }\end{array}$ \\
\hline Knowledge and human talent & $\begin{array}{l}\text { Objective } 3 \text {. To develop and promote scientific research and } \\
\text { technological innovation for a fair and solidarity-based society in } \\
\text { marine and coastal areas. }\end{array}$ \\
\hline Production and strategic sectors & $\begin{array}{l}\text { Objective } 4 \text {. Promote productive and prospecting activities for the } \\
\text { efficient, inclusive and sustainable use of the coastal, oceanic, offshore } \\
\text { and deep-sea areas. } \\
\text { Objective } 5 \text {. Promote an integrated logistics, marketing and maritime } \\
\text { transport system that is in line with national planning and international } \\
\text { demands, and that contributes to systemic competitiveness }\end{array}$ \\
\hline Sovereignty and security & $\begin{array}{l}\text { Objective 6. Promote the strategic insertion of Ecuador in the Pacific } \\
\text { Ocean and Antarctica. } \\
\text { Objective } 7 \text {. To guarantee sovereignty, sovereign rights and security at } \\
\text { sea within the framework of the Convention and other international } \\
\text { agreements signed in the oceanic and marine-coastal fields }\end{array}$ \\
\hline Transversal & $\begin{array}{l}\text { Objective } 8 \text {. Reduce vulnerability and improve adaptation of } \\
\text { populations and ecosystems to climate change and natural events } \\
\text { affecting the ocean and coastal marine area } \\
\text { Objective } 9 \text {. Establish ocean and coastal marine land-use planning that } \\
\text { articulates the various human interventions in a coherent, } \\
\text { complementary and sustainable manner }\end{array}$ \\
\hline
\end{tabular}

Ecuador's tourism policy is based on five strategic pillars: safety, destination and products, quality, connectivity and investment. Security will be integral for users and service providers. Tourist destinations will be strategically developed with planning that promotes sustainability and innovation. The quality of tourist locations will be strengthened by international standards, and the connectivity of local destinations will be promoted with the international market in order to increase the flow of tourism. The last pillar seeks to boost national and international investment in the tourism sector [53].

The policies for tourism include a regulatory framework, incentives and business climate, articulation among actors, talent and promotion. These policies are approached in a transverse manner that potentially impacts $3 S$ tourism. They aim to provide a suitable environment for the development and strengthening of the sector and touristic activities. The regulatory framework seeks to allow tourism services to accomplish minimum standards of quality, ensuring the safety of tourists. The incentives and business climate are based on creating and improving strategies aimed at boosting tourism development. Talent strengthens skills to enhance the development of tourism. Promotion, as the ultimate policy, strategically positions the country at national and international levels.

Once the tourism policy is implemented, the last aspect is to analyze its expected impacts for 2030 , i.e., GDP, employment generation, tourism investment and world ranking. GDP is expected to increase from 2.1 to 2.29 , and employment percentage is expected to increase from the current 4.7 to 8.0; it is hoped that tourism investment will increase from 4.4 to 7.5. Finally, it is expected that the world competitiveness ranking for the country will move from the 81st to the 50th place [53].

The Ministry of Tourism acts as the public governing entity. The general policy actively involves other governmental entities such as the autonomous provincial, cantonal and parish decentralized governments, and the participation of actors from both private and community sectors through tourism chambers, guilds and local communities [45]. Sustainable tourism in Ecuador is a priority of State policy and national planning, which seek to promote the integral development and rationalization of public, private and community investment. Actions and mechanisms are designed to generate 
coordinated participation with the tourism industry at the national and international levels to enhance the identified market niches, i.e., adventure tourism, cultural tourism, 3S and ecotourism; all of these will strengthen Ecuador as a tourist destination and potential country for investment [53-55].

One of the main objectives of Ecuador's foreign policy is to promote inbound tourism as a source of foreign exchange and employment. To achieve this, a 2017-2021 tourism policy has been defined based on three pillars: (i) investment, promotion and improvement of installed capacity; (ii) destination development and tourism security; and (iii) tourism services and products.

\subsubsection{Regulations}

As far as regulations are concerned, it is important to highlight the dispersed and imprecise variety of tourism regulations. The main types of regulations that refer to the management of $3 S$ tourism are laws, ordinances and regulations.

Ecuador's tourism law (Official Registry Supplement 733 of 27 December 2002) is the normative instrument that standardizes tourism activity in the country. Its purpose is to determine the legal framework that will control the promotion, development, and regulation of the tourist sector, public entities and the rights and obligations of providers and users. However, this law does not address issues related to $3 S$ tourism.

The Organic Environmental Code details that marine beaches are a national public good, so no one can claim ownership. The access and use of the beach is free for common use according to its nature (Figure 3). Marine beaches are a national good of public access, i.e., no one can claim them as their property.

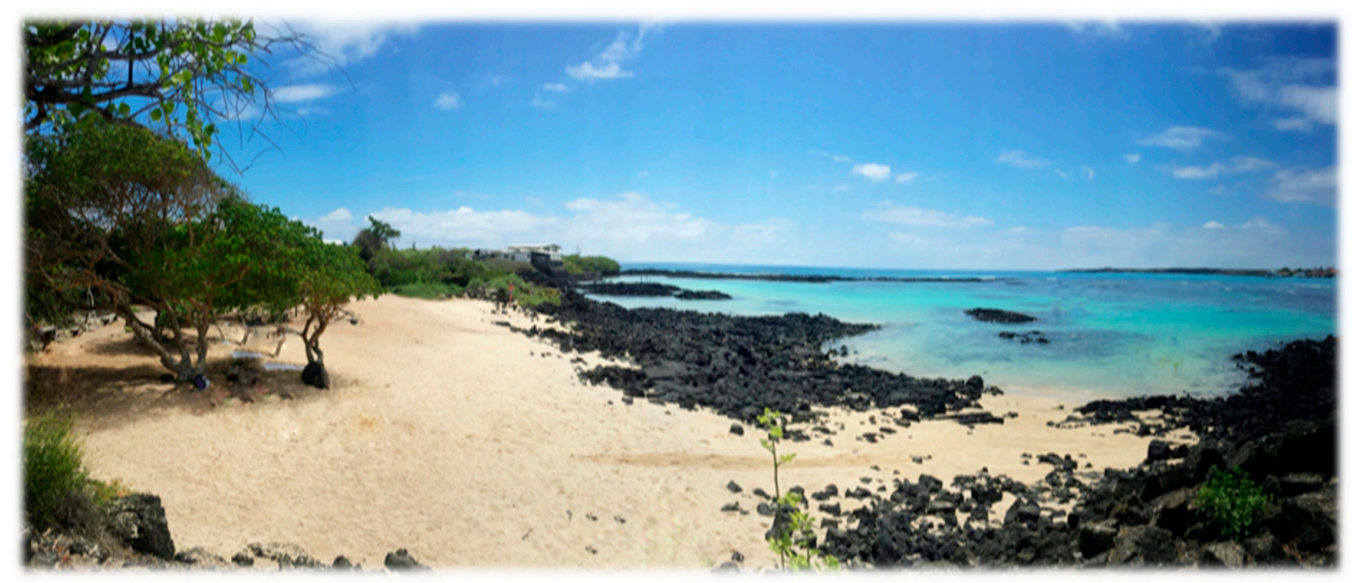

(a)

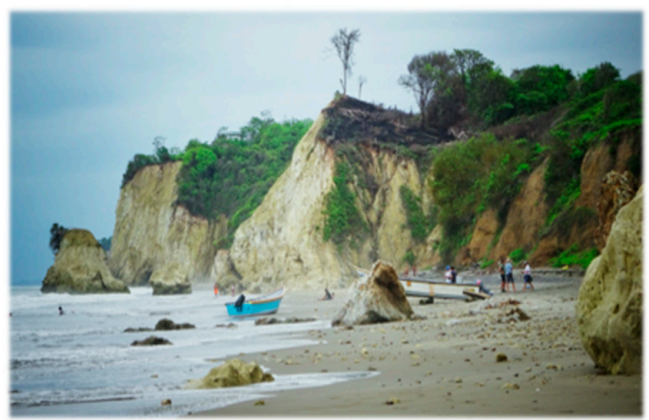

(b)

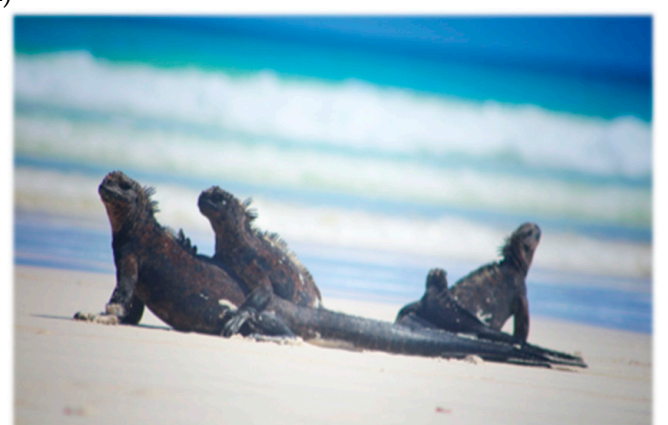

(c)

Figure 3. Public use of beaches: (a) Beach in the Galapagos Island; (b) Cliffs on the mainland; (c) Fauna on beaches, Galapagos Islands.

There is an adjacent strip of State ownership characterized by the possibility of carrying out the creation of infrastructure for the use and enjoyment of the beach. The use of the beach will be 
subject to the restrictions and prohibitions contained in this Code and other laws, in accordance with national planning for coastal marine spaces. This Code prohibits the construction, on a permanent basis, of buildings on the beach, the construction of facilities or infrastructure that impact the landscape, the destruction, modification or exploitation of the natural defenses of the beach, parking and the use of land motor vehicles, the emission of noise above permissible levels by fixed or mobile sources, the extraction of sand, shells and, in general, of nonrenewable resources, the occupation of access paths to the beach, and finally, the disposal of wasted or the placement of fences.

In 2015, the LOREG Law (Ley Organica de Regimen Especial de la provincial de Galapagos in Spanish) brought together a number of rules, policies and instruments establishing the legal framework that regulates and plans many aspects of life on the islands, e.g., uses and activities, fisheries, residency and migration, tourism, agriculture, waste management, etc. Regarding tourism aspects and according to the LOREG, it has to be sustainable and developed according to the nature-based tourism and ecotourism model, which is compatible with the conservation of the ecosystems. The management plan considers that the Galapagos must integrate an spatial planning model dealing with conservation and development, enhancing participatory and inclusive social processes for establishing good living [56]. Through the mechanisms provided by the LOREG, the case of the Galapagos islands, considered as a decentralized administrative unit, can be seen as an interesting example of IGZM.

Within the 22 studied cantons, 12 ordinances (Table 6) were found in 9 cantons, and only $11 \%$ included 35 tourism regulations. Hence, only few of them partially regulate activities such as timetables, sports activities and other activities that can be carried out on the beach.

Table 6. List of ordinances that regulate $3 S$ tourism.

\begin{tabular}{|c|c|c|c|}
\hline No. & Canton & Ordinance & Date \\
\hline 1 & \multirow{3}{*}{ Atacames } & Beach Bar operating hours & 3 April 2015 \\
\hline 2 & & $\begin{array}{l}\text { Ordinance that regulates and protects the use of the } \\
\text { exclusive zone for the "surf and similar" sport activity } \\
\text { in Atacames beach. }\end{array}$ & 6 March 2017 \\
\hline 3 & & $\begin{array}{l}\text { Ordinance regulating land occupation on the coastal } \\
\text { margin of the parishes of Tonsupa, Santa Rosa de } \\
\text { Atacames, Sua, Tonchigue, Same and the Union of the } \\
\text { Atacames Canton. }\end{array}$ & 16 April 2016 \\
\hline 4 & Pedernales & $\begin{array}{l}\text { Ordinance that regulates the powers of planning, } \\
\text { control and management for the development of } \\
\text { tourist activities. }\end{array}$ & 24 January 2019 \\
\hline 5 & San Vicente & $\begin{array}{l}\text { Ordinance that regulate the operation of tourist } \\
\text { facilities. }\end{array}$ & 2 October 2015 \\
\hline 6 & \multirow{2}{*}{ Portoviejo } & $\begin{array}{l}\text { Ordinance on the constitution of the Municipal } \\
\text { Tourism Company of Portoviejo. }\end{array}$ & 20 January 2006 \\
\hline 7 & & $\begin{array}{l}\text { Ordinance that creates and regulates the Tourism } \\
\text { Council of Portoviejo canton. }\end{array}$ & 27 October 2005 \\
\hline 8 & Jaramijó & $\begin{array}{l}\text { Ordinance that creates and regulates the planning, } \\
\text { control and management of the faculties for the } \\
\text { development of tourist activities in Jaramijó canton. }\end{array}$ & 11 December 2018 \\
\hline 9 & \multirow[b]{2}{*}{ Manta } & $\begin{array}{l}\text { Ordinance on tourism development, regulation and } \\
\text { control of beach use. }\end{array}$ & 12 November 2015 \\
\hline 10 & & $\begin{array}{l}\text { Substitute ordinance creating and regulating the fee for } \\
\text { granting a single annual license for the operation of } \\
\text { tourist facilities at Manta canton. }\end{array}$ & 22 February 2012 \\
\hline
\end{tabular}


Table 6. Cont.

\begin{tabular}{cclc}
\hline No. & Canton & \multicolumn{1}{c}{ Ordinance } & Date \\
\hline 11 & & $\begin{array}{l}\text { Ordinance regulating tourist service activities in the } \\
\text { canton of Puerto López. }\end{array}$ & 29 December 2015 \\
\cline { 3 - 4 } & \multirow{2}{*}{ Puerto López } & $\begin{array}{l}\text { Ordinance regulating the extraction of sand or other } \\
\text { materials from the beaches of the canton of } \\
\text { Puerto Lopez. }\end{array}$ & 13 December 2019 \\
\hline 13 & Sucre & $\begin{array}{l}\text { Ordinance regulating the use and control of beaches in } \\
\text { the Sucre canton }\end{array}$ & 10 January 2014 \\
\hline 14 & Salinas & $\begin{array}{l}\text { Ordinance regulating the productive activities and } \\
\text { integral management of San Lorenzo, Chipipe, La } \\
\text { Milina, Puerto Lucia and Punta Carnero beaches at } \\
\text { Salinas canton in Santa Elena Province. }\end{array}$ & 15 January 2013 \\
\hline 15 & Santa Cruz & Use of tourist piers in Santa Cruz canton. & 17 July 2012 \\
\hline
\end{tabular}

Only the canton of Salinas, in Santa Elena province, has regulations that comprehensively regulate the management of five beaches. The ordinance allows the regulation of activities, uses, concessions, delimitation, capacity of vendors, cleaning, waste management, security, lifeguards, circulation and parking of vehicles, animals allowed on the beach, infractions, sanctions and procedures on these beaches.

\subsubsection{Responsibilities}

The Constitution of the Republic of Ecuador, the Ministry of Tourism, the Ministry of Environment and the Decentralized Autonomous Municipal Governments are the entities that constitute the backbone for the regulation of $3 \mathrm{~S}$ tourism in coastal areas. The constitution assigns authority to local governments to regulate, authorize and control the use of beaches (Table 7). The Ministry of Tourism is responsible for promoting diverse destinations for $3 S$ tourism, while the Ministry of Environment is responsible for controlling and regulating $3 S$ tourism activities in protected areas [57].

Table 7. Powers of the decentralized municipal governments in relation to the management of beaches (Constitution of Ecuador).

\begin{tabular}{cl}
\hline Article & \multicolumn{1}{c}{ Description } \\
\hline & $\begin{array}{l}\text { To provide public services, i.e., drinking water, sewerage, wastewater treatment, solid } \\
\text { waste management, environmental sanitation activities and those established by law. }\end{array}$ \\
\cline { 2 - 2 } Art. 264 & $\begin{array}{l}\text { To delimit, regulate, authorize and control the use of sea beaches, riverbanks and beds, } \\
\text { lakes and lagoons, without prejudice to the limitations established by law. }\end{array}$ \\
\cline { 2 - 2 } & $\begin{array}{l}\text { To regulate, authorize and control the exploitation of arid and stony materials which } \\
\text { are found in riverbeds, lakes, sea beaches and quarries. }\end{array}$ \\
\hline \multirow{2}{*}{ Art. 375} & $\begin{array}{l}\text { Preserve and guarantee the effective access of people to beaches, riverbanks, } \\
\text { lakes and lagoons }\end{array}$ \\
\hline
\end{tabular}

Article 264 of the Constitution of the Republic of Ecuador states that the Decentralized Autonomous Municipal Governments shall have exclusive powers, without prejudice to other powers determined by law, to delimit, regulate, authorize and control the use of beaches and to preserve and guarantee effective access to their use. The Ecuadorian State will guarantee and protect public access to beaches and the existence of ways of perpendicular access [57].

The Organic Code of Territorial Organization, Autonomy and Decentralization (COOTAD) of 19 October 2010, in Article 430, also states that the Decentralized Autonomous Metropolitan and Municipal Governments shall formulate ordinances to delimit, regulate, authorize and control the use of sea beaches, as stipulated in the Constitution and the law. Article 432 empowers municipalities to implement works on beaches in order to improve the quality of life of their inhabitants [58]. 
Responsibility for the protection of coastal areas from natural hazards lies with the Committee for the Protection of the Marine and Coastal Environment of Ecuador. One of its purposes is to provide advice on protection issues to the state institutions that require it. On the other hand, it is in charge of the implementation and compliance of laws, national regulations in force, commitments derived from international conventions and treaties that have a bearing on the prevention and control of pollution of marine and coastal marine areas [59].

The Ministry of the Environment, Ministry of Tourism, and competent authorities are responsible for defining the conditions for tourism activities in protected areas according to their current management plan. Within the framework of planning instruments, it is the responsibility of the Decentralized Autonomous Governments to establish a management plan for the beach and adjacent strip as a complementary tool to the Development and Territorial Ordering Plan. The adjacent strip is owned by the state, and this may be granted concessions respecting the sustainable management of the coastal marine area and with the endorsement of the competent Decentralized Autonomous Government [58-61].

The Decentralized Autonomous Governments have begun to implement actions to develop local tourism, within the framework of the Strategic Tourism Plans. However, there is a need to formulate a Coastal Tourism Policy aimed at overcoming the problems identified in the National Tourism Competitiveness Plan and developing their own tourism products, with regional identity, which protect coastal ecosystems.

Most of the continental beaches with the greatest influx of tourists do not have protection measures. The responsibility for their management lies with the Decentralized Autonomous Governments. It is important to promote new integrated management proposals through ordinances that are in line with national policies and current legislation.

\subsubsection{Institutions}

The Ecuadorian State promotes the coordination of the different levels of national and local governments to achieve tourism objectives (Figure 4). The Ministry of Tourism is the governing body for Ecuadorian tourism activity, and is directed by the Minister of Tourism. The Ministry is in charge of generating policies and coordinating the strategies and norms to be implemented with other public institutions, in order to prevent hinderances to development.

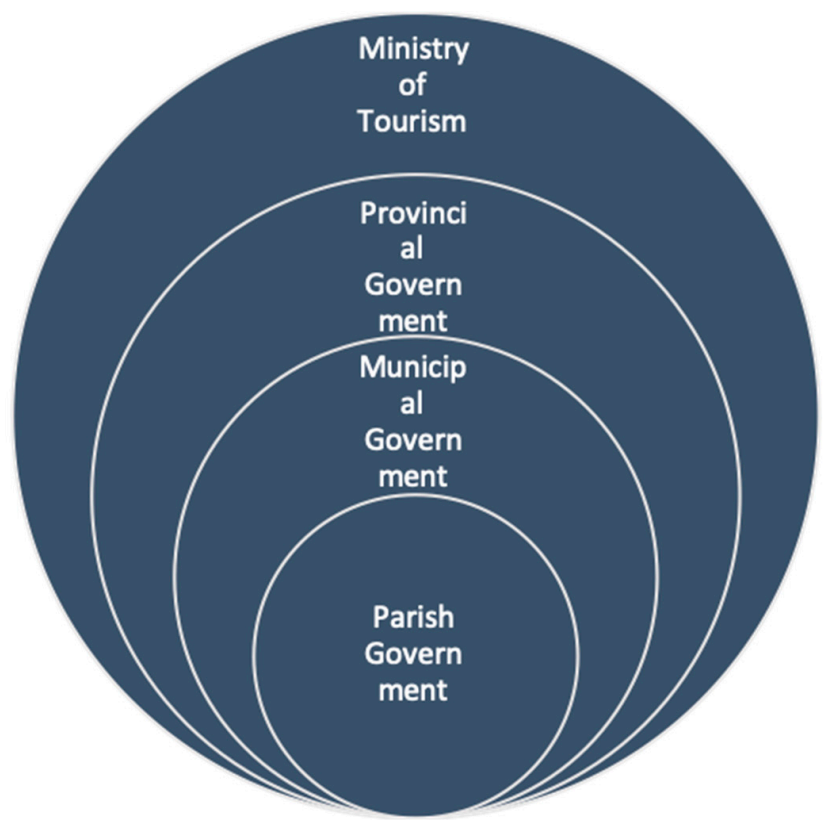

Figure 4. Hierarchy and institutional competence of tourism in Ecuador. 
As previously mentioned, the Ministry of Environment is responsible for crafting regulations and coordinating the management of the National System of Protected Area (NSPA). The NSPA is the group of natural protected areas that ensure the coverage and connectivity of important ecosystems at the terrestrial, marine and coastal marine levels; it is composed of four subsystems [61].

- $\quad$ Natural Heritage Areas (NHA) owned by the State

- $\quad$ Autonomous Decentralized Government

- Community Protected Areas (CPA)

- $\quad$ Privately owned

The NHA represents about $20 \%$ of the national territory. However, all the marine and coastal protected areas fall within this subsystem, governed by the State, with the exception of a large number of mangrove areas, which are classed within the CPA category [62]. Thereby, local governance disregards any opportunities to manage coastal and marine protected areas.

The Superintendence of Land Use and Management was created by mandate of the Organic Law of Land Use and Management. This Law states that the Superintendence will operate in a decentralized and independent manner, and will have economic and financial administrative autonomy. It is a technical entity that oversees and controls the processes of territorial planning, the use and management of land, habitat, human settlements and urban development. It contributes to the exercise of the rights of good living with an emphasis on the city and territory, in order to contribute to citizens having the same possibilities of access to a safe and healthy habitat.

The Tourism Advisory Council acts as an advisory entity for tourism activity in Ecuador. It is made up of the Ministries of Tourism, Environment, Foreign Affairs, the National Federation of Chambers of Tourism, National Tourism Associations, the Association of Municipalities, the Consortium of Provincial Councils and the Plurinational Federation of Community Tourism of Ecuador [60].

One of the institutions with the best management of beaches is the Decentralized Autonomous Municipal Government of Canton Santa Elena. Its well-established powers under ordinance highlight the adequacy of the Land Management Plan in coordination with other levels of government within the framework of its powers, the coordination with state institutions for the special administration of natural resources and tourism, the implementation of programs for the categorization and signage of beaches, establishing mechanisms for the allocation of budgetary resources for the management of beaches, the management of surveillance and control of beach activities with other institutions, and the implementation of taxes for tourism activities on the beach. The Municipal Tourism Enterprise of Santa Elena Canton regulates productive tourism activities and the integrated management of beaches through the implementation of management, surveillance and supervision of compliance with the ordinances and regulations approved by the municipal council [63].

\subsubsection{Strategies and Instruments}

The Plan for Coastal Marine Area (PCMA) is probably the most important instrument regarding IGZM in Ecuador. It is intended to address general issues related to the management of human activities and the conservation of coastal marine ecosystems. However, it has only recently been adopted (2017), and has not yet entered into force. This plan, together with others (Table 8), aims to strengthen the strategies of the ICZM and tourism. 
Table 8. Instruments of interest for the management of beaches in Ecuador.

\begin{tabular}{clc}
\hline Scale & \multicolumn{1}{c}{ Instruments and Strategies } & Date \\
\hline National & Plan for the Coastal Marine Area & 2017 \\
National & National Tourism Plan 2030 & 2019 \\
National & National Climate Change Strategy (NCCS) 2012-2025 & 2012 \\
National & Plan for Sustainable Tourism Development 2020 & 2007 \\
National & National Program for Tourism Excellence & 2014 \\
Regional & Galapagos Protected Areas Management Plan for “Good Living” & 2014 \\
National & National Biodiversity Strategy 2015-2030 & 2014 \\
\hline
\end{tabular}

The Ecuadorian government, through the Ministry of Tourism, established strategic guidelines to strengthen tourism: to improve the welfare of tourists, to increase quality, accessibility, competitivity and sustainability of tourism services (destinations, products, etc.), to increase connectivity for tourism purposes at a global scale through interinstitutional coordination, to promote entrepreneurship and investment by strengthening the national economic system, and finally, to improve the acknowledgement of Ecuadorian destinations at national and international levels to strengthen institutional capacities and efficiencies [44,46]. The main strategies are set out in the National Tourism Plan 2030, which, together with other instruments (Table 8), are intended to meet the guidelines of the Ministry of Tourism and contribute to ICZM.

The general guidelines which characterize the PCMA approach are:

- Characterization of coastal areas and main uses (cities, cantons, land uses, resources, natural and cultural heritage sites, etc.).

- Situational analysis of the coastal marine management considering the natural, political, economic, social, institutional and cultural patterns and characteristics.

- Diagnostics of the main human activities and fundaments for planning (e.g., navigation and maritime transports, fishing, aquaculture, ports, tourism, shipbuilding, urbanization, economic activities at local governance, contamination, sciences, research and innovation, protection, etc.).

- $\quad$ Proposal of sound managements strategies with monitoring indicators.

Regarding $3 S$ tourism, the PCMA shows a lack of planning for urban and village beaches (Table 3) exposed to tourism pressure due to the recent increase of recreational activities.

The strategic focus of the Ministry of Tourism in the National Tourism Plan 2030, as a guiding instrument for action in the country's tourism sector, will focus on the competitiveness of Ecuadorian destinations, with the objective of making tourism an agent of positive change in the national economy in the long term. In order to advance in this crucial task, it will be necessary to count on the actions of the private sector, the management of government apparatuses and the normative support focused on the improvement of incentives that deepen public-private alliances and, therefore, strengthen a collaborative and participative governance [54]. Tourism is considered a priority action sector for the Inter-American Development Bank. Through the Strategic Plan, the Bank intends to support the Government of Ecuador in the execution and coordination of actions aimed at the development and dynamism of the tourism sector in order to identify and develop the areas of greatest competitiveness, and maximize the positive economic impact on the population within a context of sustainable development and compliance with the Millennium Goals [47,54].

Within the National Climate Change Strategy (NCCS) 2012-2025, Ecuador is considered as a particularly sensitive country to Climate Change (CC). Indeed, it faces a variety of climate change and coastal erosion risks associated with changes in temperature and precipitation, as well as possible alterations to ocean currents [56]. This high degree of exposure is combined with the vulnerability of several economic sectors (e.g., fisheries, agriculture, infrastructure and tourism, coastal and water resources, etc.). The Galápagos Islands are among the many places already experiencing the impacts of $\mathrm{CC}$. The unique and endemic biodiversity of this World Heritage Site is at risk, and could affect the 
economy of local communities that completely depend on tourism, agriculture and fisheries $[64,65]$. Given this negative context and the urgency to act at the national scale, in 2012, Ecuador adopted a National Climate Change Strategy (2012-2025). The plan is based on two strategic lines (adaptation and mitigation) and the following structural elements: regional and international coordination, international principles on CC, local implementation, citizen participation, proactivity, protection of most vulnerable groups and ecosystem, intergenerational responsibility and environmental and integrity. Tourism, with its global perspective, is one the nine priority sectors. Among its many objectives, the NCCS aims to promote ecotourism, but did not specifically refer to 3S tourism [66].

The objectives of the National Program for Tourism Excellence are as follows: (i) to strengthen the National System of Tourism Excellence through the development of coordination and organization capacities; (ii) the promotion and dissemination of tourism excellence at the national level; (iii) to establish a National Subsystem of Tourism Training and Education through the participation and involvement of the public, private and academic sectors; (iv) to improve the National Subsystem of Tourism Quality through the generation of quality standards, certifications and the application of quality management tools; and (v) to foster and implement mechanisms that promote a culture of innovation in tourism destinations, services and products [67].

The Organic Code of the Environment says that within the framework of the planning instruments for the coastal marine space, the Decentralized Autonomous Municipal or Metropolitan Governments of the coastal marine area should establish a management plan for marine beaches and the adjacent strip as a complementary instrument to the development and territorial planning. One of the most outstanding Management Plans in coastal areas is the Environmental Management Plan of the National Recreational Area Playas of Villamil in the Canton Playas. It allows for the regulation and control of all activities carried out within this natural area. It is important to note that the municipalities in the provinces of the study area do not have comprehensive management plans [61].

The Galapagos Protected Areas Management Plan for "Good Living" is based on an integrated approach to the management of two protected areas using a single management tool. The archipelago is conceived as a whole, thus promoting an integrated and comprehensive management approach. From this perspective, the plan covers the management of almost the entire island and marine territory ( $97 \%$ island and 100\% marine). This tool proposes a conceptual and technical basis which is applicable to the whole Archipelago for the planning and territorial ordering. In this context, the plan promotes a sustainable future for local people, i.e., it maintains the ecological integrity and resilience of the ecosystems, since for the Galapagos, no conservation is possible without development and vice versa. Finally, this plan is based on a model characterized by ecosystem management, conservation of ecosystems to provide services, citizen participation and adaptive management. It is clear that the approach of the instruments in the continental zone is sectoral, except for the example of the Galapagos Management Plan, that is ecosystem-based and tends towards integrated management.

The National Biodiversity Strategy 2015-2030 is an instrument of the National Government to plan and manage biodiversity. It proposes a set of measures to guarantee the human right to live in a healthy, pollution-free and sustainable environment, as well as to protect the rights of nature. One of its Axes and Guidelines of the Productive Revolution, Work and Employment seeks to strengthen tourism based on the sustainable use of biodiversity.

\subsubsection{Training}

The National Tourism Training Plan for the period 2009-2013 was designed to reinforce the tourism sector through the transfer of technical knowledge and the development of skills and abilities to involve stakeholders in the tourism sector and improve the standards of quality in the provision of tourism services through 10 components: (1) Quality Management and Good Practices in Sustainable Tourism, (2) Training of Trainers, (3) Labor Competencies, (4) Productive Youth, (5) Hospitality and Food Security, (6) Community Tourism, (7) Specialized and Native Guides, (8) Small Tourists, (9) Productive Tourism Business and (10) Destination Management [55]. 
It is important to highlight the role played by higher education, training and certification entities in improving productivity and employability in the tourism industry. The supply of university education has increased; in 2014 a total of 52 universities were registered, 42 of which included 117 degrees in tourism, hotel management and tourism, and hotel management at a national level.

One of the strategies in the axis of Destination and Quality is to strengthen, specialize and innovate training, certification of professional qualifications and technical degrees that guarantee the professionalization of employees in the sector. This represents a pillar on which the user experiences and the excellence of the quality of the $3 S$ touristic offer are built. The plans, programs and actions implemented in this strategic axis seek to boost tourism training and excellence that will promote the professionalization of management spaces, from decision-making to operational levels, with emphasis on local government instances. These training programs also foster technical assistance and continuous tourism certification that promotes the professionalization of the actors involved in $3 S$ tourism activities regarding the management and operational spheres. The programs also seek to promote the optimization of future jobs, the valorization of traditional jobs and the incorporation of digital skills, aimed at the different actors of the tourism activity, with emphasis on decentralized governments [54].

The strategic axis of tourism security seeks to promote permanent training processes for tourism service providers, especially for tourist guides in matters of tourist safety and first aid. The plans, programs and actions implemented in this strategic area are coordinated with the National Disability Equality Council and the National Federation of Ecuadorians with Physical Disabilities to promote training processes in the areas of awareness, tourism and accessibility to the physical environment.

It is important to mention that Ecuadorian educational institutions are affiliated or are part of important networks in the region related to ICZM: The Ibero-American University Association of Postgraduate Studies (AUIP), whose general objective is to contribute to the training of university professors, scientists and professionals at the postgraduate and doctoral level, according to the development needs of each country and the Ibero-American Community of Nations [68]. The Ibero-American Network of Integrated Coastal Management (IBERMAR), composed of 200 researchers in 16 countries, contributes to the fulfillment of global and regional commitments related to the Ibero-American coastal space [69]. Also, the PROPLAYAS Network, present in 15 countries of Latin America and the Iberian Peninsula, is a platform of collaborative exchange in the management and certification of beaches, founded by scientists, activists and businessmen with a common objective: the integrated management of the coastal-marine ecosystem [70].

In 2016, WildAid, an international nonprofit organization with offices in the Galapagos, developed a plan to strengthen the control and surveillance of the Coastal Marine Protected Areas of Continental Ecuador according to a concept of long-term economic sustainability. The main activities of the National Control Plan focus on strengthening mobilization, communication, surveillance, detection, legal framework, staff capacities, control operations and evaluation mechanisms in the coastal marine spaces of the protected areas. It is concluded that it is necessary to develop a comprehensive training program to improve ICZM.

\subsubsection{Economic Resources}

The planned budget of the Ministry of Tourism presented an increasing allocation from 2008 to 2011. Then, this budget allocation saw a dramatic decrease in 2012, remaining partially stable until 2016, but decreasing again between 2017 and 2018, causing a decrease in the activities carried out. The Ministry had a comprehensive vision of sustainable tourism, and it can be seen that Tourism Marketing and Promotion Axis are the most executed activities, despite the fact that a lower budget was assigned in the initial planning, since the private counterpart was expected to deliver higher incentives for the sector [54].

For the year 2018, the Ministry of Tourism had an execution budget of $95.60 \%$. Compliance with allocated resources for investment in various projects reached $70.00 \%$, while values within the 
current subject were executed at $98.59 \%$. The trend of foreign arrivals has always revealed a clear growth that has not been affected, despite its decrease in 2016 and 2017 due to external factors such as the dollar appreciation and the earthquake that occurred in April 2016. Tourism revenues reached USD 2398.1 million by the end of 2018 and represented the third largest source of nonoil revenues. The country has recorded a surplus in the tourism budget for seven consecutive years. Tourism also shows a multiplier effect of $1.6 \%$ on the national economy. The total contribution of tourism to GDP reaches $5.51 \%$, of which $2.28 \%$ is direct. Additionally, domestic tourism turns over 7.6 million dollars a day $[47,54]$.

Nonetheless, one of the biggest problems with 35 tourism in the coastal municipalities is the low budget allocation for strengthening and fulfilling the strategic axes established by the government through the Ministry of Tourism. It is fundamental to emphasize that the beaches offer enormous economic benefits through their different uses and services. Well managed beaches bring social benefits [71]; this is the case of Puerto Lopez (Manabi province), an ancient fishing village converted into a base for whale watching. In 2014, the direct revenue related to humpback watching at Machalilla National Park was estimated to be around US\$1,100,000, while indirectly, US $\$ 1,800,000$ was spent by whale watchers on tourism related activities between June to September [72].

\subsubsection{Information}

The Ministry of Tourism has established a system of market and research intelligence that identifies priority markets and products in order to define promotional actions that fit national and international tourist trends. These actions should allow effective market approaches to be devised. Studies have been carried out to identify the profile of foreign tourists in Ecuador, their average expenditure on tourist activities and nights spent in the country. The results indicate that $30 \%$ of visitors carry out activities related to $3 \mathrm{~S}$ tourism.

The country has also carried out general research on 3S tourism. The gathered data from these studies, directed by the Ministry of Tourism, contributed to building a macro but very superficial idea about this type of tourism, which does not address the needs of the different actors involved in $3 S$ tourism. The scarce information in coastal jurisdictions about $3 S$ tourism does not allow for adequate management decisions to be made.

Few research projects have focused upon $3 S$ tourism on Ecuador's coasts; existing studies focus rather on coastal management [4,17] and beach pollution [4]. Even coastal universities are not carrying out research projects to promote $3 S$ tourism. Problems are evident in the interinstitutional relations between the central and local governments regarding to the application of strategies to strengthen $3 S$ tourism. The constant changes of cantonal and provincial tourism directors and the lack of well-defined skills hinder actions that could be executed jointly.

It is important to mention that the most used means of propagation of tourist information for travel planning is the Internet. Among the most visited sites is the official website of the Ministry of Tourism of Ecuador and the virtual platform TripAdvisor [54]. However, a problem that is evident and persistent in $3 \mathrm{~S}$ tourism is the lack of information about tourist services; such information is not available on electronic platforms [53].

In terms of the Promotion and Marketing of 3S tourism, there is evidence of an adaptation of tourist information and promotion to the new conditions of demand, which, above all, seek uniqueness and customization of information processes. This shall be transferred to digital projects and social media marketing plans that aim to publish guides and promotional material on both digital and offline channels. It is imperative to adapt this content to new mobile tools which are available for tourists, who are currently much more informed and demanding of new services. It is also essential to incorporate virtual spaces in which the tourist can interact with the destination and with other users [54].

Tourist information about 3S destinations in Ecuador can be found at www.playasonline.ec. This page informs tourists about beaches in the provinces of Esmeraldas, Manabi, Santa Elena and 
Guayas along Highway E15 "Troncal del Pacifico", or as it is known worldwide, the "Via del Pacifico". The "Ruta del Spondylus", i.e., a governmental initiative to promote coastal tourism, is also detailed. There is more information on traditional travel platforms (Tripadvisor, Booking, takeoff), which promote beaches in all-inclusive packages. The national government and tourism entities do not have an official page to promote coastal tourist destinations.

\subsubsection{Education for Sustainability}

In Ecuador, there is a policy of education in coastal areas to promote sustainable tourism [53-55]. One of the strategies of the Ministry of Tourism is oriented toward the implementation of campaigns in educational institutions, at both general basic education and general unified high school levels. These strategies are expected to increase awareness about the importance of tourism for the country, strengthening the destination identity and stimulating the consumption of national tourist services.

Regarding education about the sustainability of the coastal profile and its beaches (Figure 5), initiatives have been developed for the population [54]. The adopted measures are based on incorporating content related to the preservation of the marine coastal space into educational networks; knowledge is imparted through projects. For example, the Ibero-American University Foundation (FUNIBER) Sede Ecuador, collaborates with the project "Sustainable Beaches: Development of an integrated solid waste and environmental management system for the tourist canton of Playas and its area of influence", which is financed by the European Union (EU). This project seeks to convert the coastal canton of Playas into a quality tourist destination based on the integrated management of waste with the active participation of all actors in society, generating awareness and respect for the environment.

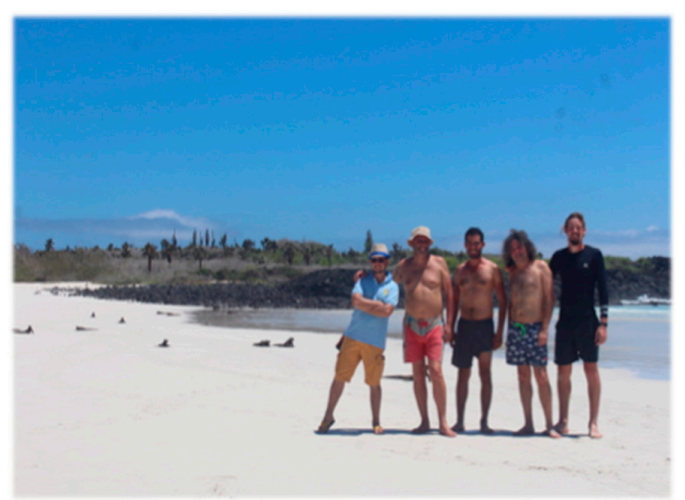

(a)

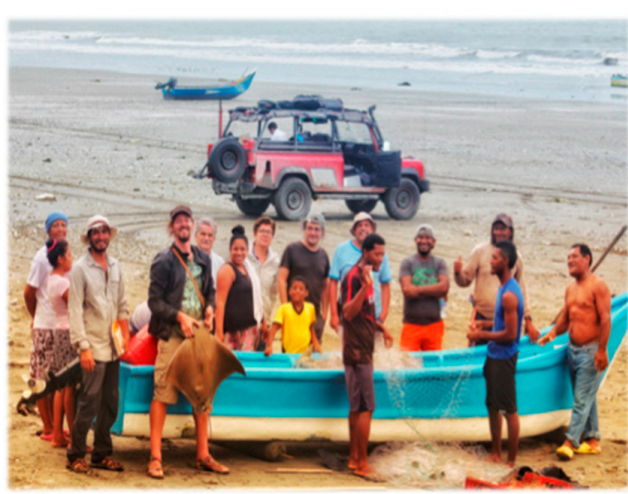

(b)

Figure 5. Education for sustainability, research group socializing the study with local population: (a) Researchers in Galapagos Island; (b) Researchers in Esmeraldas Province.

The Undersecretariat of Marine and Coastal Management carries out activities related to the final disposal of solid waste, from waste collection activities to environmental education campaigns. In 2018, with the help of other organizations (Conservation International and Coca Cola Foundation), a Coastal Cleanup program was started in seven protected areas, collecting $7979.7 \mathrm{~kg}$ of solid waste. This added to a cleanup initiative in Manta by the Clean Up of the World campaign, where $720 \mathrm{~kg}$ of waste was collected, giving a total of $8699.70 \mathrm{~kg}$. There were also cleanings of the sea floor where a total of $148.70 \mathrm{~kg}$ was extracted, and a mangrove campaign was carried out where $2819.99 \mathrm{~kg}$ of garbage was extracted, of which almost $80 \%$ was plastic. In the $2019,6291.66 \mathrm{~kg}$ of waste was collected from the same seven APMCs [73].

\subsubsection{Citizen Participation}

A citizen participation program is promoted by the Central Government through the Ministry of Tourism to ensure compliance with the rules in the territorial districts of decentralized autonomous 
governments with regard to tourism, and therefore, $3 \mathrm{~S}$ activities. In the approved ordinances on $3 \mathrm{~S}$ tourism, all social actors participated in the elaboration and socialization processes prior to their implementation.

Tourism enterprises in the Ecuadorian coastal zone have formed tourism development committees whose objective is to propose strategies that consider citizen participation as the main axis for the development of coastal territories, in order to convert them into quality tourism destinations. Among the main powers of the committees is to receive delegation from the Ministry of Tourism, to carry out before the Ministry of Tourism or other authorities the necessary actions for the benefit of their delegation, to inform the Minister of Tourism about aspects related to the tourism branch within its jurisdiction, and others assigned to them by the Minister of Tourism. The tourism committees will elect their secretary and function on the basis of regulations that will be issued for this purpose. Tourism committees shall not intervene in matters related to regulation, control, elaboration or national or local planning, nor in the elaboration of tourism policies $[60,74]$.

The Council of Citizen Participation and Social Control has been consolidated as a collective space of contribution and work to bring about an environment in which everyone is an active part of the planning, management and decision making in a democratic and participatory state. This institution has organized various workshops, one of the most important of which was the event on the Organizational Strengthening of Communities, Towns and Nationalities on the Ecuadorian Coast. It took place in La Libertad canton, Santa Elena province, on 25 October 2018. Meetings and workshops like this one are frequent in the coastal cantons, with the participation of delegations from communes in the provinces of Guayas, Santa Elena, Manabí and Esmeraldas, indigenous Guancavilcas peoples and nationalities, traditional fishermen's organizations and associations of the Rural Social Security. The main objective of the meetings is to strengthen initiatives, including the strengthening of tourism and measures to reduce maritime and coastal pollution [75].

\subsection{Sea, Sun and Sand (3S) Tourism SWOT}

The results (Table 9) of the review are presented below (SWOT: Strengths, Weaknesses, Opportunities and Threats).

Table 9. SWOT analysis.

\begin{tabular}{|c|c|c|c|}
\hline Strengths & Weaknesses & Opportunities & Threats \\
\hline $\begin{array}{ll}\text { - } & \text { New tourism policy } \\
\text { - } & \text { Citizen participation } \\
\text { - } & \text { established responsibilities } \\
\text { Various institutions are } \\
\text { involved in tourism } \\
\text { Integrated approach } \\
\text { developed in the } \\
\text { Galapagos Islands } \\
\text { Marine and costal protected } \\
\text { areas of great relevance with } \\
\text { high biodiversity and scenic } \\
\text { values (e.g., Machalilla } \\
\text { National Park). }\end{array}$ & $\begin{array}{ll}\text { - } & \text { Low } \\
\text { integral regulations } \\
\text { - } \\
\text { Political and } \\
\text { administrative changes } \\
\text { Education } \\
\text { for sustainability } \\
\text { - } \quad \text { Outdated Regulations } \\
\text { Lack of unity, planning } \\
\text { and control of 3S } \\
\text { tourism in a global } \\
\text { manner at } \\
\text { mainland country. } \\
\text { Regional competition } \\
\text { between cantons }\end{array}$ & $\begin{array}{ll}\text { - } & \text { Good } \\
\text { tourist promotion } \\
\text { Decentralization: it } \\
\text { is both a challenge } \\
\text { and an opportunity } \\
\text { for cross scale } \\
\text { coordination, local } \\
\text { empowerment and } \\
\text { IGZM initiatives. } \\
\text { Increase of } \\
\text { international and } \\
\text { national tourists } \\
\text { visits and boost } \\
\text { demand for } \\
\text { ecotourism (e.g., } \\
\text { Whale Watching) }\end{array}$ & $\begin{array}{l}\text { - Decrease in } \\
\text { economic resources } \\
\text { CC related processed (erosion, } \\
\text { storms events, sea level rise, } \\
\text { etc.), and potential impacts on } \\
\text { coastal economy. } \\
\text { Contaminated waters due to } \\
\text { industrial activities } \\
\text { (agricultural, mining, ground } \\
\text { water exploitation). } \\
\text { - Urbanization processes related } \\
\text { to rapid grow and lack } \\
\text { of control. } \\
\text { Poor management by the } \\
\text { governing entities } \\
\text { COVID-19 }\end{array}$ \\
\hline
\end{tabular}

After the results obtained through the analysis of aspects of the Decalogue, a summary synthesis of the main strengths, weaknesses, opportunities and threats (SWOT) of 3S tourism in continental Ecuador and the Galapagos Islands were determined, four aspects stood out as strengths (Policies, Responsibilities, Institutions and Citizen participation), while the most notable weaknesses were Regulations and Education for Sustainability. The notable opportunities are Strategies, Instruments and Information, and the main threats are Economic resources and Training. 


\section{Discussion}

Compared to other countries in the region, Ecuador has more policies and regulation instruments regarding ICZM tourism $[30,76,77]$ but it lacks clear regulations on coastal tourism.

The Central Government has implemented tourism as a public policy, and intends to consolidate it as a dynamic element of economic and social development. Despite such attempts, one of the greatest problems is the assignment of skills for the implementation of these policies and the creation of instruments that can regulate activities, uses, concessions and other procedures on beaches. There is a strong requirement for an update of the $3 S$ tourism regulations that focus on new trends and preferences. Poor management by the governing entities (Decentralized Cantonal Autonomous Governments) of the coastal space has caused its scenic beauty to diminish notably; this was also due to unfavorable natural conditions [4].

The central government's programs and strategies for tourism development in the last ten years are evident [55], as are those planned for the next ten years [54], but the programs and strategies have not been established. Presently, the political will is to generate a better business environment and consolidate a portfolio of opportunities which will allow Ecuador to be positioned as a recognized destination on the national and international markets.

As far as instruments are concerned, Ecuador can be inspired by others countries. For example, in Latin America and the Caribbean, four countries approved their National ICZM Plans or Programs: Barbados, Belize, Brazil and Puerto Rico [20]. Following the model of the USA, Puerto Rico adopted the ICZM Program of Puerto Rico in 1978 (later revised in 2009) in response to issues related to risks, coastal resources, coastal development, recreation, fishing, etc., and proposals to address these issues (e.g., development in public and private ownership, active management of natural resources, promotion of sustainable development, research). The cases of Belize and Barbados (both from 1998) are proof of the success of international cooperation. Both exhibit very important strategic content and approaches. Lastly, Brazil approved most instruments in the last two decades, even if doubts still exist about their application in coastal provinces [19].

To ensure the future viability of economic activities that support a growing coastal population, it is necessary to conserve ecosystems and their services. Is important to propose an Integrated Coastal Zone Management plan, taking examples of appropriate management from Europe [78,79], Africa [80], and Latin America $[19,21]$. Success lies in the existence of efficient coordination among the different levels of administration (national, regional and local) and the social actors involved, as well as in the legislation and policies in this area. Thus, much of the success of an ICZM program is linked to the continuity of actions over time: for this reason it is mandatory to guarantee sustainable financing. In 2012, Ecuador developed the INEN 2631:2012 certification standard that establishes the requirements that beaches must meet to obtain a tourist quality certification in order to improve activities related to the $3 \mathrm{~S}$ tourism and other modalities. This norm has never been applied due to the lack of political will, regulation and information of the local authorities in charge of beach management $[46,81]$. Hence, Ecuador missed a great opportunity provided by this standard and its certification scheme as an effective tool for ICZM.

The management of Ecuadorian beaches suffers from serious problems. Currently, such places derive the maximum economic benefit but not the sustainability of the ecosystem that will make a continuous flow of services possible; this was evident in other studies $[17,71]$. In order to implement sustainable tourism practices, the direct involvement of government officials, civil society and the active participation of economic agents is required. This is a determining factor in promoting synergy between tourists and locals by encouraging sustainable tourism practices. Research in recent years [82] indicates that a major problem has been the lack of coordination and communication among the actors involved. This lack of coordination is caused by individual interests in the different power groups; a clear example of this was in the canton of Playas, where big businessmen put pressure on the authorities to obtain decisions that favored them, leaving aside possible inclusive integral management [83]. The present study shows a similar problem in cantons where there is incipient inclusive social participation; 
locals have repeatedly shown that power groups are the ones who make the decisions regarding management. Therefore, it is vital that a process of cooperation among local actors be carried out in order to achieve inclusive development strategies, projects and programs.

By promoting inclusive development strategies, projects and programs, it is possible to comply with the guidelines for coordination between the Territorial Development and Management Plan with Agenda 2030 and the ODS Sustainable Development Objectives [84]. This will contribute to the positioning and potential of Ecuador as a megadiverse, intercultural and multiethnic country, developing and strengthening the national tourism and cultural industries, and promoting receptive tourism as a source of foreign exchange and employment, within a framework of protection of natural and cultural heritage. Achieving sustainable tourism will also create jobs and promote local culture and products.

\section{Conclusions}

Ecuador does not have a clearly established scheme concerning public responsibilities that takes the integrated management of $3 \mathrm{~S}$ tourism into account. In order to strengthen $3 \mathrm{~S}$ within the national tourism system, it is essential to (i) maintain constant monitoring in terms of area coordination (public/private), (ii) encourage credibility and confidence in the institutional frameworks of all parties involved, from the central state to the decentralized regimes, and (iii) apply rigorous strategic planning for tourism development based on technological tools and updated statistical information that provides an attractive business climate for investors.

It is necessary to consolidate and promote $3 S$ tourism as a State policy and as a source of improvement for the economies of coastal areas, and to intensify public and private investment for the development of tourism and the construction of a favorable environment (i.e., a business climate) for investment with legal security.

In short, it is necessary to implement clear policies that will allow Ecuador to promote a model based on competitiveness and sustainability. To encourage the effective use of its natural and cultural coastal attractions, we must stimulate the creation of other innovative resources and improve the efficiency of services. It is also essential to improve universal accessibility, information and communication technologies.

Ecuador needs to overcome negative changes in the macroeconomic environment and reverse the deteriorated image it has due to criminal events, social/political upheaval and natural disasters. It is also of relevance to draw upon successful international experiences in the management, promotion, investment, regulation and control of the country's tourism activities, and to offer unique tourism experiences to heterogeneous, informed and motivated tourists who are seeking unique and diverse experiences.

The effects of COVID-19 in Ecuador will cause tourism revenues in 2020 to fall by approximately 70\% compared to 2019. The National Government, through the Ministry of Tourism, and the Decentralized Autonomous Governments in coastal areas, must propose policies and strategies to mitigate the impact of this. Government economic projects and programs are needed to reactivate tourism, offer a safe destination and monitor the beaches. It is important that the new policies for $3 S$ tourism adapt to the new reality caused by COVID-19. In addition the current situation is complicated in a country that does not take advantage of its tourism potential in comparison with other countries in South America.

Finally, 3S tourism should be considered as an alternative of great value that minimizes the negative effect on coastal ecosystems. The principles for the formulation of this policy must have an impact on the environmental problems generated by this activity on coastal areas. Local governments and governmental institutions in charge of its management are a key element in the development of the activity; they must promote comprehensive legislation which takes into account the fact that coastal tourism is one of the most dynamic economic activities in Latin America. 
Author Contributions: Conceptualization, C.M.-R., J.A.C.-R. and G.A.; Formal analysis, J.A.C.-R., G.A., A.M., C.M.B. and E.P.; Funding acquisition, C.M.-R.; Investigation, C.M.-R., J.A.C.-R. and G.A.; Methodology, C.M.-R., J.A.C.-R. and G.A.; Project administration, J.A.C.-R.; Validation, J.A.C.-R., C.M.B., A.M., G.A. and E.P.; Writing - original draft, C.M.-R. and J.A.C.-R.; Writing-review \& editing, C.M.-R., J.A.C.-R., G.A. and A.M.; All authors have read and agree to the published version of the manuscript.

Funding: This research was funded by Instituto Superior Tecnológico Universitario Oriente (Grant No. IDI2386).

Acknowledgments: The authors are grateful for the financial support of Instituto Superior Tecnológico Universitario Oriente and for the support of researchers from the Universidad de Cádiz (UCA), PROPLAYAS network, Escuela Superior Politécnica de Chimborazo (ESPOCH) and Instituto Tecnológico Superior Oriente (ITSO).

Conflicts of Interest: The authors declare no conflict of interest.

\section{References}

1. Alipour, H.; Arefipour, T. Rethinking potentials of Co-management for sustainable common pool resources (CPR) and tourism: The case of a Mediterranean island. Ocean Coast. Manag. 2020, 183, 104993. [CrossRef]

2. Mooser, A.; Anfuso, G.; Mestanza, C.; Williams, A. Management Implications for the Most Attractive Scenic Sites along the Andalusia Coast (SW Spain). Sustainability 2018, 10, 1328. [CrossRef]

3. Williams, A.T.; Rangel-Buitrago, N.G.; Anfuso, G.; Cervantes, O.; Botero, C.M. Litter impacts on scenery and tourism on the Colombian north Caribbean coast. Tour. Manag. 2016, 55, 209-224. [CrossRef]

4. Mestanza, C.; Botero, C.M.; Anfuso, G.; Chica-Ruiz, J.A.; Pranzini, E.; Mooser, A. Beach litter in Ecuador and the Galapagos islands: A baseline to enhance environmental conservation and sustainable beach tourism. Mar. Pollut. Bull. 2019, 140, 573-578. [CrossRef]

5. Simcock, A. Tourism BT-Handbook on Marine Environment Protection: Science, Impacts and Sustainable Management; Salomon, M., Markus, T., Eds.; Springer International Publishing: Cham, Switzerland, 2018; pp. 327-349. ISBN 978-3-319-60156-4.

6. Ariza, E.; Sardá, R.; Jiménez, J.A.; Mora, J.; Ávila, C. Beyond Performance Assessment Measurements for Beach Management: Application to Spanish Mediterranean Beaches. Coast. Manag. 2007, 36, 47-66. [CrossRef]

7. DeAngelis, M.B.; Sutton-Grier, E.A.; Colden, A.; Arkema, K.K.; Baillie, J.C.; Bennett, O.R.; Benoit, J.; Blitch, S.; Chatwin, A.; Dausman, A.; et al. Social Factors Key to Landscape-Scale Coastal Restoration: Lessons Learned from Three U.S. Case Studies. Sustainability 2020, 12, 869. [CrossRef]

8. Enriquez-Acevedo, T.; Botero, C.M.; Cantero-Rodelo, R.; Pertuz, A.; Suarez, A. Willingness to pay for Beach Ecosystem Services: The case study of three Colombian beaches. Ocean Coast. Manag. 2018, 161, 96-104. [CrossRef]

9. Zinzani, A. International Development Policies and Coastalscape Metabolism: The Case of the Mekong Delta, Vietnam. Soc. Sci. 2018, 7, 19. [CrossRef]

10. Gerhartz-Abraham, A.; Fanning, L.M.; Angulo-Valdes, J. ICZM in Cuba: Challenges and opportunities in a changing economic context. Mar. Policy 2016, 73, 69-76. [CrossRef]

11. Nava Fuentes, J.C.; Arenas Granados, P.; Martins, F.C. Coastal management in Mexico: Improvements after the marine and coastal policy publication. Ocean Coast. Manag. 2017, 137, 131-143. [CrossRef]

12. Barragán, J.M.; Lazo, Ó. Policy progress on ICZM in Peru. Ocean Coast. Manag. 2018, 157, 203-216. [CrossRef]

13. Pérez-Cayeiro, M.L.; Chica-Ruiz, J.A. Evaluation of a programme of integrated coastal zone management: The Ecoplata Programme (Uruguay). Mar. Policy 2015, 51, 527-535. [CrossRef]

14. Barragán Muñoz, J.M.; Dadon, J.R.; Matteucci, S.D.; Morello, J.H.; Baxendale, C.; Rodríguez, A. Preliminary basis for an integrated management program for the coastal zone of Argentina. Coast. Manag. 2003, 31, 55-77. [CrossRef]

15. Barragán Muñoz, J.M. The Brazilian National Plan for Coastal Management (PNGC). Coast. Manag. 2001, 29, 137-156. [CrossRef]

16. Rangel-Buitrago, N.; Contreras-López, M.; Martínez, C.; Williams, A. Can coastal scenery be managed? The Valparaíso region, Chile as a case study. Ocean Coast. Manag. 2018, 163, 383-400. [CrossRef]

17. Mestanza-Ramón, C.; Sanchez Capa, M.; Figueroa Saavedra, H.; Rojas Paredes, J. Integrated Coastal Zone Management in Continental Ecuador and Galapagos Islands: Challenges and Opportunities in a Changing Tourism and Economic Context. Sustainability 2019, 11, 6386. [CrossRef] 
18. Botero, C.M.; Fanning, L.M.; Milanes, C.; Planas, J.A. An indicator framework for assessing progress in land and marine planning in Colombia and Cuba. Ecol. Indic. 2016, 64, 181-193. [CrossRef]

19. Barragán Muñoz, J.M. Progress of coastal management in Latin America and the Caribbean. Ocean Coast. Manag. 2020, 184, 105009. [CrossRef]

20. Caviedes, V.; Arenas-Granados, P.; Barragán-Muñoz, J.M. Regional public policy for Integrated Coastal Zone Management in Central America. Ocean Coast. Manag. 2020, 186, 105114. [CrossRef]

21. Milanés Batista, C.; Planas, J.A.; Pelot, R.; Núñez, J.R. A new methodology incorporating public participation within Cuba's ICZM program. Ocean Coast. Manag. 2020, 186, 105101. [CrossRef]

22. Maestro, M.; Pérez-Cayeiro, M.L.; Chica-Ruiz, J.A.; Reyes, H. Marine protected areas in the 21st century: Current situation and trends. Ocean Coast. Manag. 2019, 171, 28-36. [CrossRef]

23. Uehara, T.; Niu, J.; Chen, X.; Ota, T.; Nakagami, K. A sustainability assessment framework for regional-scale Integrated Coastal Zone Management (ICZM) incorporating Inclusive Wealth, Satoumi, and ecosystem services science. Sustain. Sci. 2016, 11, 801-812. [CrossRef]

24. Luís, S.; Lima, M.L.; Roseta-Palma, C.; Rodrigues, N.; Sousa, L.P.; Freitas, F.; Alves, F.L.; Lillebø, A.I.; Parrod, C.; Jolivet, V.; et al. Psychosocial drivers for change: Understanding and promoting stakeholder engagement in local adaptation to climate change in three European Mediterranean case studies. J. Environ. Manag. 2018, 223, 165-174. [CrossRef]

25. Gallagher, A. The coastal sustainability standard: A management systems approach to ICZM. Ocean Coast. Manag. 2010, 53, 336-349. [CrossRef]

26. Hakim, M.; Hakim, A.; Hakim, L.; Harahab, N. Coastal Tourism Management Model toward Developing Independent Tourist Village in Central Lombok District, Indonesia. Resources 2018, 7, 69. [CrossRef]

27. Parrinello, G.; Bécot, R. Regional Planning and the Environmental Impact of Coastal Tourism: The Mission Racine for the Redevelopment of Languedoc-Roussillon's Littoral. Humanities 2019, 8, 13. [CrossRef]

28. Pulido-Fernández, D.M.; Pulido-Fernández, I.J. Is There a Good Model for Implementing Governance in Tourist Destinations? The Opinion of Experts. Sustainability 2019, 11, 3342. [CrossRef]

29. Mestanza, C.; Saavedra, H.F.; Gaibor, I.D.; Zaquinaula, M.A.; Váscones, R.L.; Pacheco, O.M. Conflict and impacts generated by the filming of Discovery Channel's reality series "Naked and Afraid" in the Amazon: A Special case in the Cuyabeno Wildlife Reserve, Ecuador. Sustainability 2018, 11, 50. [CrossRef]

30. Shahzad, S.J.H.; Shahbaz, M.; Ferrer, R.; Kumar, R.R. Tourism-led growth hypothesis in the top ten tourist destinations: New evidence using the quantile-on-quantile approach. Tour. Manag. 2017, 60, $223-232$. [CrossRef]

31. Barbier, E.B. Marine ecosystem services. Curr. Biol. 2017, 27, R507-R510. [CrossRef]

32. Mestanza, C.; Piccardi, M.; Pranzini, E. Coastal erosion management at Callao (Peru) in the 17th and 18th centuries: The first groin field in South America? Water 2018, 10, 981. [CrossRef]

33. Alexandrakis, G.; Manasakis, C.; Kampanis, N.A. Valuating the effects of beach erosion to tourism revenue. A management perspective. Ocean Coast. Manag. 2015, 111, 1-11. [CrossRef]

34. Yepes Piqueras, V. Las playas en la gestión sostenible del litoral. Cuad. Tur. 1999, 1, 89-110.

35. Turner, R.K.; Bower, B.T. Principles and benefits of integrated coastal zone management (ICZM). In Perspectives on Integrated Coastal Zone Management; Springer: Berlin/Heidelberg, Germany, 1999; pp. 13-34.

36. Mestanza, C.; Llanos, D.; Herrera Jaramillo, R.V. Capacidad de carga turística para el desarrollo sostenible en senderos de uso público: Un caso especial en la reserva de producción de fauna Cuyabeno, Ecuador. Caribeña Ciencias Soc. 2019, 5, 5-22. [CrossRef]

37. Haq, S.M. Ecology and Economics: Implications for integrated coastal zone management. In Coastal Zone Management Imperative for Maritime Developing Nations; Springer: Berlin/Heidelberg, Germany, 1997; pp. 1-27.

38. Carter, N.H.; Schmidt, W.S.; Hirons, C.A. An International Assessment of Mangrove Management: Incorporation in Integrated Coastal Zone Management. Diversity 2015, 7, 74-104. [CrossRef]

39. Beitl, C.M. The Changing Legal and Institutional Context for Recognizing Nature's Rights in Ecuador: Mangroves, Fisheries, Farmed Shrimp, and Coastal Management since 1980. J. Int. Wildl. Law Policy 2016, 19, 317-332. [CrossRef]

40. Instituto Nacional de Estadísticas y Censos. Una Mirada Historica a la Estadística del Ecuador; Primera; El Telegrafo: Quito, Ecuador, 2015; ISBN 9942-07-967.

41. Barragán, J.M. Politica, Gestión y Litoral: Una Nueva Visión de la Gestión Integrada de Áreas Litorales; Editorial Tébar Flores: Madrid, Spain, 2014; ISBN 8473605187. 
42. Ministerio de Turismo del Ecuador-MINTUR. Perfil de Turismo Internacional 2017; Alvaracín, M., Gallegos, F., Lafuente, F., Eds.; MINTUR: Quito, Ecuador, 2018.

43. Williams, A.; Micallef, A. Beach Management: Principles and Practice; Routledge: Abingdon, UK, 2009; ISBN 1849770034.

44. Botero, C.M.; Cervantes, O.; Finkl, C.W. Beach Management Tools-Concepts, Methodologies and Case Studies; Springer: Berlin/Heidelberg, Germany, 2017; Volume 24, ISBN 3319583042.

45. Wright, L.D.; Short, A.D. Morphodynamic variability of surf zones and beaches: A synthesis. Mar. Geol. 1984, 56, 93-118. [CrossRef]

46. Zielinski, S.; Botero, C. Are eco-labels sustainable? Beach certification schemes in Latin America and the Caribbean. J. Sustain. Tour. 2015, 23, 1550-1572. [CrossRef]

47. Senplades, S.N. Plan Nacional de Desarrollo 2017-2021 Toda una Vida; Naciones Unidas: New York, NY, USA, 2017.

48. Instituto Oceanográfico de la Armada del Ecuador-INOCAR. Derrotero de la Costa Continental e Insular del Ecuador; Proaño, M., Ed.; INOCAR: Guayaquil, Ecuador, 2011.

49. Consejo de Gobierno del Régimen Especial de Galápagos Plan de Desarrollo Sustentable y Ordenamiento Territorial del Régimen Especial de Galápagos; Puerto Baquerizo Moreno: Galápagos, Ecuador, 2015; ISBN 978-9942-22-059-2.

50. Villacís, B.; Carrillo, D. País Atrevido: La Nueva cara Sociodemográfica del Ecuador, 1st ed.; Instituto Nacional de Estadística y Censos (INEC): Quito, Ecuador, 2012.

51. Barragán Muñoz, J.M. Manejo costero Integrado y Política Pública en Iberoamérica: Un diagnóstico. Necesidad de cambio; Granados, P.A., Chica Ruiz, J.A., Javier, G.O., García Sanabria, J., Eds.; Red IBERMA: Cádiz, Spain, 2010; Volume 1, ISBN 978-8469251751.

52. Setemar. Políticas Públicas Costeras y Oceánicas: Diagnóstico y Propuesta de Implementación; Biótica Cía. Ltd.: Guayaquil, Ecuador, 2014.

53. Ministerio de Turismo del Ecuador-MINTUR. Politica de Turismo del Ecuador; MINTUR: Quito, Ecuador, 2017.

54. Ministerio de Turismo del Ecuador-MINTUR. Plan Nacional de Turismo 2030; MINTUR: Quito, Ecuador, 2019.

55. Ministerio de Turismo del Ecuador-MINTUR. Plan Estratégico De Desarrollo De Turismo Sostenible Para Ecuador "Plandetur 2020"; MINTUR: Quito, Ecuador, 2009; Volume 15.

56. IUCN. Report of the IUCN Reactive Monitoring Mission to Galápagos Islands (Ecuador), 21-25 August 2017; IUCN: Gland, Switzerland, 2017.

57. Asamblea Constituyente del Ecuador. Constitución de la República del Ecuador; Comisión Legal: Montecristi, Ecuador, 2008.

58. Asamblea Nacional del Ecuador Código Orgánico de Organización Territorial, Autonomía y Descentralización. Quito C (2012) Ord. Metrop. 2010, 171, 10-34.

59. Ministerio de Transporte y Obras Publicas del Ecuador. Comité de Protección del Medio Marino y Marítimo Costero del Ecuador; MTOP: Quito, Ecuador, 2018.

60. Ministerio de Turismo del Ecuador-MINTUR. Ley de Turismo; MINTUR: Quito, Ecuador, 2002.

61. Ministerio del Ambiente del Ecuador. Código Organico del Ambiente; MINTUR: Quito, Ecuador, 2017.

62. Moksness, E.; Dahl, E.; Støttrup, J.G. Global Challenges in Integrated Coastal Zone Management; Wiley Online Library: Hoboken, NJ, USA, 2013; ISBN 0470657561.

63. Gobierno Autónomo Descentralizado Municipal del Catón Santa Elena. Ordenanzas que Regula las Actividades Turísticas Productivas y Manejo Integral de las Playas; GAD Santa Elena: Santa Elena, Ecuador, 2016.

64. Secretaria Nacional de Planificación y Desarrollo. Plan de Ordenamiento del Espacio Marino Costero; SEMPLADES: Quito, Ecuador, 2017.

65. Sachs, J.P.; Nemiah Ladd, S. Climate and oceanography of the Galapagos in the 21st century: Expected changes and research needs. Galapagos Comment. 2010, 1, 50-54.

66. República del Ecuador Ministerio del Ambiente. Estrategia Nacional de Cambio Climático del Ecuador 2012-2025; República del Ecuador Ministerio del Ambiente: Quito, Ecuador, 2012.

67. Ministerio de Turismo del Ecuador-MINTUR. Programa Nacional para la Excelencia Turística; MINTUR: Quito, Ecuador, 2014.

68. Fines y Objetivos. Available online: https://www.auip.org/es/presentacion/fines-y-objetivos (accessed on 20 April 2020).

69. Red IBERMAR-CEI-MAR. Available online: http://www.campusdelmar.com/es/red-ibermar/ (accessed on 20 April 2020). 
70. Inicio. Available online: http://www.proplayas.org/ (accessed on 20 April 2020).

71. Zambrano-Monserrate, M.A.; Silva-Zambrano, C.A.; Ruano, M.A. The economic value of natural protected areas in Ecuador: A case of Villamil Beach National Recreation Area. Ocean Coast. Manag. 2018, 157, $193-202$. [CrossRef]

72. Scheidat, M.; Castro, C.; Gonzalez, J.; Williams, R. Behavioural responses of humpback whales (Megaptera novaeangliae) to whalewatching boats near Isla de la Plata, Machalilla National Park, Ecuador. J. Cetacean Res. Manag. 2004, 6, 63-68.

73. Kelvin Ponce Campuzano, A.L.; Minchala Jiménez, P.A. Ciclo de Conferencias de Biodiversidad Marino-Costera Red de Áreas Protegidas Marino Costeras; Subsecretaría de Gestión Marina y Costera. 2017. Available online: https:/chm.cbd.int/api/v2013/documents/93C2EF63-A827-68BB-42D1-72B9AE92669F/ attachments/RESUMENES_FORO2.pdf (accessed on 9 June 2020).

74. Ministerio de Turismo del Ecuador-MINTUR. Reglamento General a la Ley de Turismo; MINTUR: Quito, Ecuador, 2004.

75. Consejo de Participación Ciudadana y Control Social. Rendición de Cuentas 2019; CPCCS: Quito, Ecuador, 2019.

76. Rangel-Buitrago, N.; Correa, I.D.; Anfuso, G.; Ergin, A.; Williams, A.T. Assessing and managing scenery of the Caribbean Coast of Colombia. Tour. Manag. 2013, 35, 41-58. [CrossRef]

77. Pranzini, E.; Anfuso, G.; Botero, C.-M.; Cabrera, A.; Campos, Y.A.; Martinez, G.C.; Williams, A.T. Sand colour at Cuba and its influence on beach nourishment and management. Ocean Coast. Manag. 2016, 126, 51-60. [CrossRef]

78. Klinger, T. International ICZM: In search of successful outcomes. Ocean Coast. Manag. 2004, 47, 195-196. [CrossRef]

79. Vousdoukas, M.I.; Mentaschi, L.; Hinkel, J.; Ward, P.J.; Mongelli, I.; Ciscar, J.-C.; Feyen, L. Economic motivation for raising coastal flood defenses in Europe. Nat. Commun. 2020, 11, 2119. [CrossRef] [PubMed]

80. Ibrahim, H.S. Towards an effective framework for coastal zone management: The Egyptian experience. J. Coast. Conserv. 2013, 17, 601-613. [CrossRef]

81. Botero, C.-M.; Williams, A.; Cabrera, J. Advances in Beach Management in Latin America: Overview from Certification Schemes; Springer: Cham, Switzerland, 2014; Volume 8, pp. 33-63.

82. Leposa, N. Problematic blue growth: A thematic synthesis of social sustainability problems related to growth in the marine and coastal tourism. Sustain. Sci. 2020, 15, 1233-1244. [CrossRef]

83. Santos, J.L.Q. Sostenibilidad sociocultural del turismo: Propuestas para el cantón Playas. Provincia del Guayas, Ecuador. Rev. Espiga 2016, 15, 31-43. [CrossRef]

84. Secretaría Técnica Planifica Ecuador. Lineamientos para la Articulación entre el Plan de Desarrollo y Ordenamiento Territorial con la Agenda 2030 y los Objetivos de Desarrollo Sostenible ODS; SEMPLADES: Quito, Ecuador, 2019. 